\title{
THE POTENTIAL OF Garcinia dulcis (ROXB.) KURZ. AS A SOURCE OF HYDROXYCITRIC ACID AND ITS HABITAT CONDITIONS
}

\author{
RINA R. IRWANTO* and HERIAN STIYANI \\ School of Life Sciences \& Technology, ITB, Jalan Ganesa 10, Bandung, Indonesia \\ *E-mail: rina@sith.itb.ac.id
}

Accepted 1 May 2020, Published online 6 July 2020

In Indonesia, between 1993 and 2014, the prevalence of overweight adults alarmingly doubled from $17.1 \%$ to $33.0 \%$ (Oddo et al., 2019). Some people thus started looking for weight loss procedures, specifically from natural compounds in plants instead of treatment from medical practitioners. Hydroxycitric acid (HCA) is a compound used as a component in obesity and cholesterol-lowering drugs. HCA has the potential to inhibit the synthesis of fat and cholesterol (Moffet,1998). HCA is a derivate of citric acid, which is found in a variety of plants, including Garcinia. In G. cambogia, HCA is found in the fruit, stems and leaves, with the highest quantity in fruit (Heymsfield, 1998). Other plant species such as asam gelugur (G. atroviridis), asam kandis (G. parvifolia) and mundu (G. dulcis) are also high in their HCA content (Isnawati, 1997; Wuryandari, 1998). In asam gelugur, the percentage of HCA is $92.9 \%$, while in asam kandis it is $83.1 \%$. However, little is known about HCA content in G. dulcis.

Garcinia dulcis (Roxb.) Kurtz, known in Indonesia as mundu, is a member of the Clusiaceae (Guttiferae) family. This species has many synonyms namely; Garcinia elliptica Choisy, Garcinia longifolia Blume, Stalagmitis dulcis (Roxb.) Cambess., Stalagmitis javanensis (Blume) Spach, Xanthocymus dulcis Toxb. and Xanthocymus javanensia Blume (Lim, 2012). G. dulcis is a perennial tree with a height of 5-12 meters. The leaves are ovate to oblong-elliptic in shape, measuring 10-30 $\mathrm{cm} \times 3.5-14 \mathrm{~cm}$ (Figure 1). The flowers are axillary, yellow-white in colour, possess a sour odour and generate 5-merous. The male flowers are in small clusters, and measure around $6 \mathrm{~mm}$ wide. The female flowers are $12 \mathrm{~mm}$ wide with a pedicel $1.5-3 \mathrm{~cm}$ long and with 5-lobed stigma. Flowering usually occurs between OctoberDecember. The average fruit produced by each tree in one season accumulates to approximately 60-70

* To whom correspondence should be addressed. $\mathrm{kg}$. The fruit are spherical, measuring $5-8 \mathrm{~cm}$ wide and crowned by the persistent stigma. The skin is thin, soft and light yellow when ripe. The fruit has a thick rind (mesocarp), fleshy endocarp and 5-6 seeds. The fruit contains a variety of chemical compounds, including 42 xanthones derivatives, as well as organic acids such as citric acid, fumaric acid and other organic acids (Heymsfield, 1998). Although it is said that the fruit can be eaten fresh, preserved or made into fruit paste/jam (Lim, 2012), villagers in Klahang rarely eat them due to their sweet taste, high acidity and a specific flavour known locally as gummy. Local people utilise its woody stems for building materials. The species is indigenous to Peninsular Malaysia, Southern Thailand, Java, Borneo and the Philippines (Lim, 2012). Although widely grown in Indonesia, especially in Java and Kalimantan, its potential is not widely known. Therefore, this study was conducted to determine the concentration of HCA in mundu fruit and record the environmental habitat condition. The research was performed in Desa Klahang, Kecamatan Sokaraja, Kabupaten Banyumas, in Central Java.

HCA compounds were revealed to be present in the rind and seeds of $G$. dulcis. An average area of HCA peak appeared at a retention time of 3:03 min. The standard deviation value of retention time was 0.004676 , while the average value was 3.038333 . The result was similar with several studies about HCA, which also had the value of retention time within the range of three minutes (Vinh et al., 2011). The standard calibration of HCA showed the value of the linear regression as, $y=11123 x+136316$ (Figure 2), with a correlation coefficient (R2) = 0.9056 .

Mundu rind samples had an average peak area larger than seeds, i.e. 9.261.73, while the seeds were 9.136.51. Broad peak value area of two samples was then converted into concentration of HCA. Mundu fruit skin produced HCA as much as 32.67 grams $/ 100$ gram sample, while the seeds 


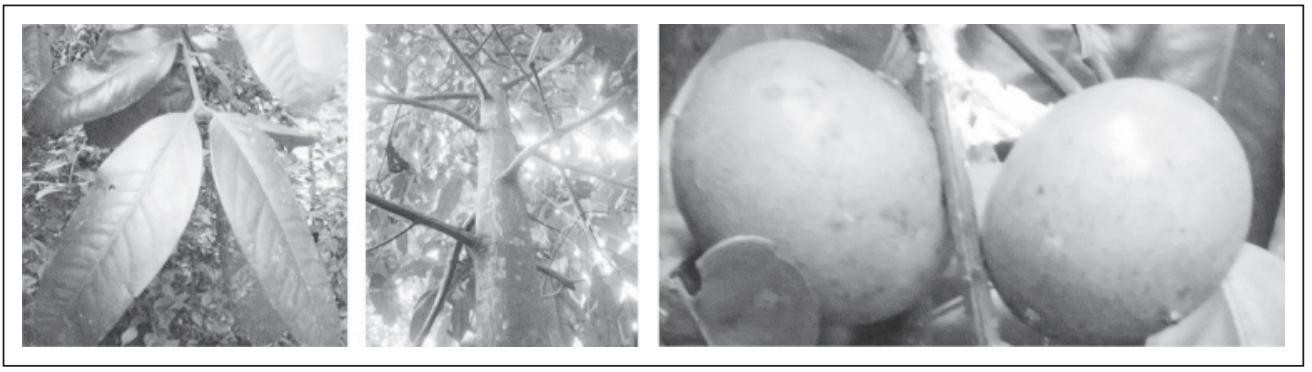

Fig. 1. Leaves, branches and fruit of Garcinia dulcis grow in Desa Klahang.

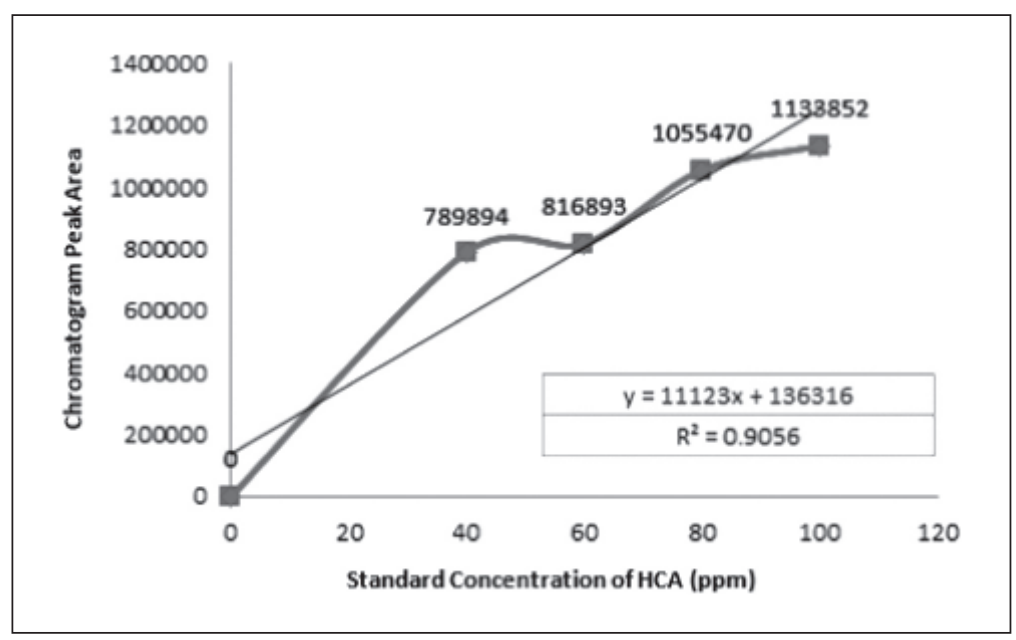

Fig. 2. Calibration graph of HCA at different concentration.

Table 1. The comparison of HCA concentration of six species of Garcinia

\begin{tabular}{lc}
\hline Garcinia spesies & $\begin{array}{r}\text { Concentration of HCA } \\
(\mathrm{g} / 100 \mathrm{~g} \text { sample })\end{array}$ \\
\hline G. oblongifolia & 9.508 \\
G. cowa & 11,23 \\
G. india & 11,50 \\
G. cambogia & 17,00 \\
G. dulcis & 32,67 \\
\hline
\end{tabular}

produced 32.23 grams/100 grams from seed samples. HCA concentration of $G$. dulcis was higher than $G$. oblongifolia, G. cowa, G. indica and G. cambogia, which were analyzed using the same extraction method (Table 1). G. cambogia as a source of hydroxycitric acid, which has been widely used as a weight loss drug, contained as much as $16-18$ grams /100 grams of HCA (Vinh et al., 2011).

Plant species distribution was strongly influenced by soil nutrients, environmental conditions as well as land topography. In Klahang village, $G$. dulcis naturally grew in two groups, with a total of 35 trees having different ages. These plants were only found in the garden or yard area in which vegetation was still maintained, and in areas with a closed canopy. G. dulcis were not found in open areas such as residential areas or rice fields. However, this plant tends to grow near rivers. The range of altitudes of $G$. dulcis was 30-45 meters above sea level. G. dulcis population was most commonly found at an altitude between 38-42 meters above sea level (Figure 3). These results contrast with (Heyne, 1987) who discovered that G. dulcis prefered an altitude of around 500 meters above sea level. This could be possible due to other environmental factors affecting the growth of $G$. dulcis more than altitude, such as soil and air conditions. Environmental conditions of the G. dulcis habitat were as follows: air temperature was $29^{\circ} \mathrm{C}$ and relative humidity was $73 \%$. Soil organic and organic content was $71 \%$ and $88 \%$ respectively. Soil moisture was $23 \%$ and soil temperature was $28.8^{\circ} \mathrm{C}$. The $\mathrm{N}, \mathrm{P}, \mathrm{K}$ and $\mathrm{C}$ contents had the values of $12.19 \mathrm{mg} / \mathrm{kg}, 85.82 \mathrm{mg} /$ $100 \mathrm{~g}, 62.20 \mathrm{mg} / 100 \mathrm{~g}$, and $1.76 \mathrm{mg} / \mathrm{kg}$ respectively (Table 2). Referring to soil criteria from the Indonesia Ministry of Land (2014) the value of P and $\mathrm{K}$ soil with $25 \% \mathrm{HCl}$ extract is considered high (Hutchinson et al., 1998). Overall, our findings of 


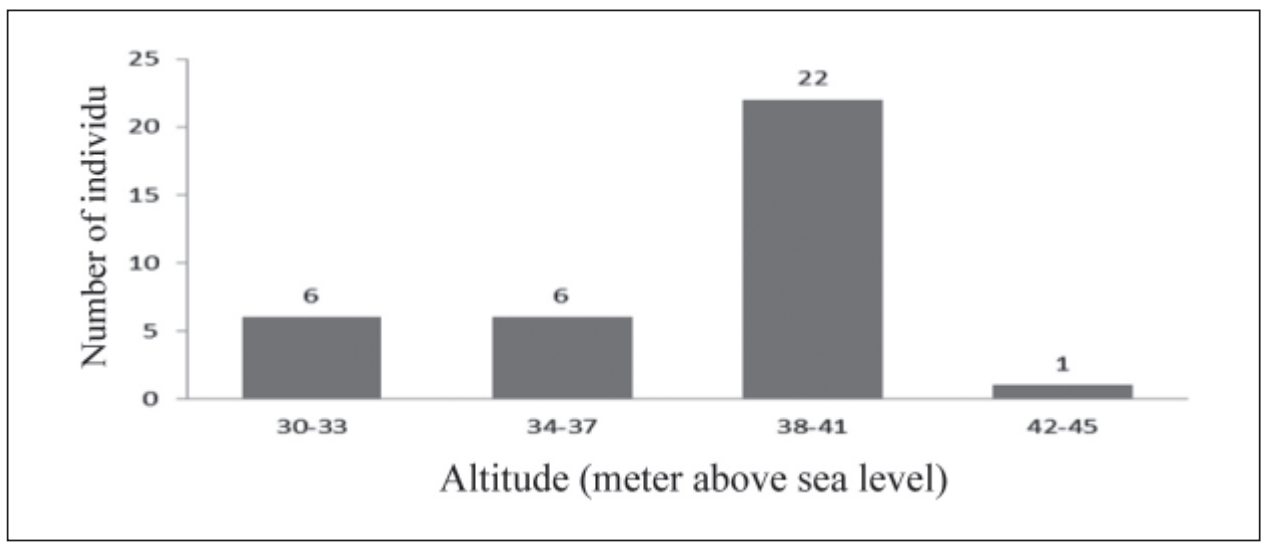

Fig. 3. Distribution of Garcinia dulcis at different altitude in Klahang, Central of Java, Indonesia.

Table 2. Soil condition of $G$. dulcis in Klahang village in Desa Klahang

\begin{tabular}{lc}
\hline Soil Parameter & Value \\
\hline Nitrogen $(\mathrm{mg} / \mathrm{kg})$ & 0.19 \\
Posfor $(\mathrm{mg} / 100 \mathrm{~g})$ & 85,82 \\
Kalium $(\mathrm{mg} / 100 \mathrm{~g})$ & 62,20 \\
Carbon $(\mathrm{mg} / \mathrm{kg})$ & 1,76 \\
$\mathrm{pH}$ & $4.4-5.8$ \\
Temperature $\left({ }^{\circ} \mathrm{C}\right)$ & 29.8 \\
\hline
\end{tabular}

the environment of mundu habitat was similar to the findings of Lim (2012), showing that mundu preferred to grow in humid areas, in land areas up to $500 \mathrm{~m}$ above sea level and was not fastidious to soil types.

Nutrient and soil chemical elements, as well as the acidity $(\mathrm{pH})$ of the soil, plays an important role in the survival of plants. The content of nitrogen in the soil is a major factor limiting the growth of trees in ecosystems (Sollins, 1998: Hutchinson et al., 1998). Composition of carbon and nitrogen in the soil indicate the level of soil organic matter (Sollins, 1998). The value of $\mathrm{C} / \mathrm{N}$ ratio is 9.3 , and is almost equal to the $\mathrm{C} / \mathrm{N}$ ratio of compost. Therefore, soil is categorized as arable but the level of organic matter is stable (Leu, 2012).

The ratio of sand, clay and silt in the soil in Klahang was 36.67: 32.33: 31.00 , respectively, thus the soil can be categorized as clay soil (Soil Survey Staff, 2014), which has good capacity to hold water. Therefore, it tends to be wet due to its fine particles holding more water and more closely than sand. Based on the soil data of G. dulcis habitat, it can be suggested that G. dulcis growing in Desa Klahang is a fertile soil with both high levels of organic and inorganic matter, as well as high water holding capacity.
HCA concentration in the rind of Garcinia dulcis was (32.67 grams/100 grams of sample) which was higher than the fruit seed sample (32.23 grams/ 100 grams of sample). The concentration of HCA in G. dulcis was higher compared to other Garcinia species that has been widely studied and used as a weight loss drug. The habitat conditions of G. dulcis in Klahang had the characteristics as follows: living in the lowlands (30-45 meters above sea level), possessing air temperature ranging from $29^{\circ} \mathrm{C}$, with air humidity $73 \%$. The soil was classified as clay soil, with soil temperature of $28.8^{\circ} \mathrm{C}$, and was rich in mineral. Organic content and concentration of $\mathrm{N}, \mathrm{P}, \mathrm{K}$ was high and it also has an acidic $\mathrm{pH}$ level.

\section{ACKNOWLEDGMENTS}

We are grateful to Miss Annapurna for correcting the manuscript and ICMNS Editorial Team who gave the chance to publish our research in this journal.

\section{REFERENCES}

Heymsfield, S.B., Allison, D.B., Vasselli, J.R., Pietrobelli, A., Greenfield, D. \& Nunez, C. 1998. Garcinia cambogia (hidroxycitric acid) as a potential anti-obesity agent. Jama Original Contribution 280: 1596-1600.

Heyne, K. 1987. Tumbuhan berguna Indonesia (translation), De nuttige planten van Nederland Vol 3, 600 pp Departemen Kehutanan, Jakarta. 
Hutchinson, T.F.R., Boerner, E.J., Iverson, L.R. \& Sutherland, E.K. 1998. Landscape patterns of understory composition and richness across a moisture and nitrogen mineralization gradient in Ohio (U.S.A) Quercus forests. Plant Ecology 144(14): 177-189.

Isnawati, F. 1997. Produksi Asam Hidroksi sitrat dan garam-garamnya dari sari buah Gelugur (G. atroviridis)1q. Final Project. Department of Chemistry, FMIPA, IPB. Bogor.

Leu, A. 2012. Soil organic matter: tips for responsible nitrogen management. Ecofarming Daily magazine. August Issue.

Lim, T.K. 2012. Edible Medicinal and NonMedicinal Plants Vol. 2 Fruit: 988 pp, Springer, Dordrecht.

Moffet, S.A. 1998. Hydroxycitric Acid Concentrate and Food Products Prepared Thereform. United State: United State Patent Office. United State: United State Patent Office.
Oddo, V.M., Maehara, M. \& Jee Hyun Rah. 2019. Overweight in Indonesia: an observational study of trends and risk factors among adults and children. BMJ Open. Sep 1, 2019.

Soil Survey Staff. 2014. Kunci Taksonomi Tanah. Edisi Ketiga, 2015. Balai Besar Penelitian dan Pengembangan Sumberdaya Lahan Pertanian, Badan Penelitian dan Pengembangan Pertanian.

Sollins, P. 1998. Factors influencing species composition in tropical lowland rain forest: does soil matter? Ecology 79: 23-39.

Vinh, D.Q., Cuong, D.H. \& Thuong, N. 2011. Extracting (-)-hydroxycitric acid from dried rinds of Garcinia oblongifolia Champ. ex Benth by using microwave. Journal of the Korean Chemical Society 55(6): 983-987.

Wuryandari, H.T. 1998. Analisis asam dan garam dari sari buah gelugur dan kandis (Garcinia atrovidis dan Garcinia parfivolia) secara konvensional. Skripsi Jurusan Kimia FMIPA IPB. Bogor. 